\title{
MUSA DAN KEPEMIMPINANNYA DALAM KITAB KELUARAN
}

\author{
SIA KOK SIN
}

\section{ABSTRAKSI}

Tulisan ini dipersembahkan untuk Pdt. Kornelius A. Setiawan, D.Th. yang menjalankan kepemimpinan sebagai Rektor atau Ketua STT Aletheia dalam periode 2003-2013. Dalam masa 10 tahun kepemimpinan beliau, Tuhan telah memakainya menjalankan peran yang khusus dan khas dalam sejarah perkembangan STT Aletheia. Paling tidak ada 2 hal besar dalam era ini yang sangat menonjol, yaitu pembangunan pelbagai gedung yang dibutuhkan dalam pendidikan di STT Aletheia dan diakreditasinya STT Aletheia oleh Badan Akreditasi Nasional. Penulis mengenal beliau sebagai seorang pribadi yang selalu berupaya memberikan yang terbaik dalam pengabdian dan pelayanannya. Dalam kaitan dengan hal ini, penulis sengaja memilih topik kepemimpinan Musa dalam kitab Keluaran sebagai penghargaan dan upaya mengingat peran Pdt. Kornelus sebagai seorang pemimpin yang dipilih, diperlengkapi dan dimampukan oleh Allah untuk menjalankan perannya sebagai Rektor atau Ketua STT Aletheia.

Kata Kunci: kepemimpinan umum, kepemimpinan Musa, kitab Keluaran

Dalam buku Charisma and Authority in Israelite Society Rodney R. Hutton menyelidiki tentang kepemimpinan dalam sejarah Israel. ${ }^{1} \mathrm{Di}$ bagian pendahuluan bukunya Hutton membahas 3 tipe kepemimpinan berdasarkan teori Max Weber yaitu kepemimpinan traditional yang hidup dalam "community" (kelompok masyarakat kecil dan erat hubungannya), kepemimpinan legal atau rational yang hidup dalam "society" (kelompok masyarakat yang mempunyai tatanan yang rumit dan dapat berlangsung oleh karena adanya kesepakatan dalam tata hidup bersama), kepemimpinan karismatis

${ }^{1}$ Rodney R. Hutton, Charisma and Authority in Israelite Society (Minneapolis: Fortress Press, 1994. 
yang tak terikat oleh struktur masyarakat dalam bentuk "community" atau "society". ${ }^{2}$ Kepemimpinan karismatis diberikan kepada pribadi yang ingin mengupayakan struktur baru baik didukung ataupun tidak didukung oleh kekuasaan yang diakui oleh masyarakat. ${ }^{3}$ Namun Hutton berpendapat bahwa karisma tak dapat dilepaskan begitu saja dengan institusi. ${ }^{4}$ Karisma mempunyai hubungan yang kompleks dengan institusi. ${ }^{5}$

Dalam kaitan dengan kepemimpinan Musa, Hutton mengangkat permasalahan: apakah kekuasaan Musa itu karismatis atau institusi. ${ }^{6}$ Hutton mengungkapkan bahwa para ahli mula-mula umumnya menekankan aspek karismatik pada Musa dan menganggapnya sebagai pendiri agama yang karismatis, cikal bakal nabi yang karismatis, dll. ${ }^{7}$ Tetapi akhir-akhir ini para ahli mulai mengangkat aspek institusional dari peran Musa. ${ }^{8}$ Selanjutnya Hutton menuliskan:

"One can only use the language of paradox to describe Moses' symbolic function: he is "nonrepeatable archetype" who is "paradigmatically unique." His persona symbolizes the convergence of the forces of "charisma" and "institution."

Jadi topik Musa dan perannya sebagai pemimpin merupakan suatu topik yang menarik untuk diselidiki dan diselusuri. George W. Coats mengungkapkan bahwa pemimpin Kristen masa kini dapat mempelajari pola kepemimpinan Musa bagi pelayanannya. ${ }^{10}$

Dalam menyelidiki Musa berdasarkan ilmu kepemimpinan, penulis mendasarkan ilmu kepemimpinan yang ditulis oleh Kartini Kartono. ${ }^{11}$ Memang penulis dengan sengaja memilih ilmu kepemimpinan umum dalam meneliti topik ini, sehingga dalam

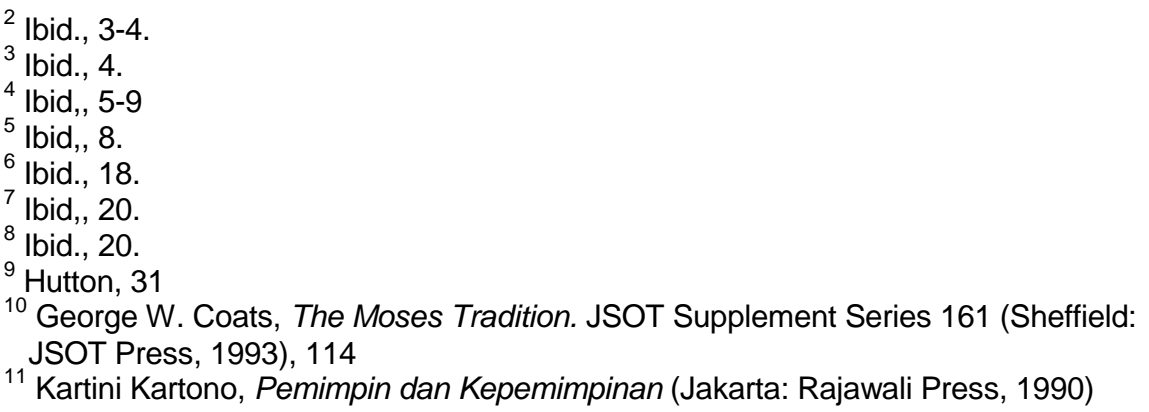


pembahasan tentang peran Musa sebagai pemimpin dapat dimunculkan aspek-aspek kepemimpinan yang khas dari Alkitab, khususnya kitab Keluaran.

\section{Kemampuan atau Kecakapan Khusus Merupakan Hal Utama Bagi Kepemimpinan Umum}

Dalam mendefinisikan seorang pemimpin Kartini Kartono menuliskan:

"Seorang PEMIMPIN adalah pribadi yang memiliki kecakapan khusus, dengan atau tanpa pengangkatan resmi dapat mempengaruhi kelompok yang, untuk melakukan usaha bersama mengarah pada pencapaian sasaran-sasaran tertentu."

Selanjutnya Kartini Kartono mengungkapkan 3 teori tentang kemunculan seorang pemimpin, yaitu: ${ }^{13}$

1. Teori genetis yang berpendapat bahwa seorang pemimpin itu tidak dibuat, tetapi dilahirkan dengan bakat-bakat tertentu untuk menjadi seorang pemimpin.

2. Teori sosial yang berpendapat bahwa seorang pemimpin harus disiapkan, dididik dan dibentuk.

3. Teori ekologis yang berpendapat bahwa seorang pemimpin sukses adalah seorang lahir dengan bakat-bakat kepemimpinan, lalu mendapat persiapan dan pembinaan untuk menjadi pemimpin yang sesuai dengan tuntutan lingkungan atau ekologisnya.

Penjelasan Kartini Kartono tentang seorang pemimpin menekankan mutlaknya kepemilikan akan kecakapan atau kemampuan tertentu seseorang pemimpin. Kecakapan atau kemampuan kepemimpinan ini dapat saja dimiliki seseorang melalui bawaan genetis, pendidikan ataupun keduanya.

\footnotetext{
12 lbid, 35.

13 lbid., 29.
} 


\section{Panggilan Ilahi Merupakan Hal Utama Kepemimpinan Alkitabiah}

Jika seseorang menyelusuri kepemimpinan Musa dalam kitab Keluaran, ia akan menemukan ada hal lain yang penting bagi seorang pemimpin, yaitu panggilan Ilahi. Kepemimpinan Alkitabiah menekankan mutlaknya panggilan llahi bagi seorang pemimpin. Panggilan Ilahi inilah yang melahirkan atau menyebabkan munculnya seorang pemimpin. Kepemimpinan Alkitabiah tak dapat dilepaskan dari rencana Allah bagi seseorang ataupun umat Allah.

Keluaran 3 mengungkapkan panggilan Allah bagi Musa untuk menjadi seorang pemimpin, khususnya ayat 11 yang mengungkapkan: "Jadi sekarang, pergilah, Aku mengutus engkau kepada Firaun untuk membawa umat-Ku, orang Israel, keluar dari Mesir." Allah memanggil Musa untuk memimpin orang Israel keluar dari perbudakan Mesir. Panggilan dan penjabaran tugas kepemimpinan yang jelas bagi Musa.

Dalam rencana-Nya Allah mempersiapkan dan memanggil Musa untuk menjadi seorang pemimpin. Sebelum memanggil Musa sebagai seorang pemimpin, Allah telah mempersiapkan Musa jauh sebelumnya. Dalam rencana-Nya Allah menyelamatkan Musa dari perintah Firaun untuk membunuh seluruh bayi laki-laki orang Ibrani, bahkan Musa diangkat sebagai anak oleh puteri Firaun (Kel. 2). W.H. Grispen mengungkapkan bahwa Musa kecil ini mendapat pendidikan terbaik Mesir dalam pelbagai ilmu sebagai hak yang diterimanya sebagai anak puteri Firaun. ${ }^{14}$ Allah dalam rencana-Nya mempersiapkan Musa dengan hal-hal yang dibutuhkan untuk menjadi seorang pemimpin. James Nohnberg mengungkapkan bahwa Musa adalah "a Hebrew Egyptian and an Egyptian Hebrew"15 Dualitas ini merupakan bagian persiapan Allah untuk Musa sebagai pemimpin yang membebaskan bangsa Israel dari kekuasaan bangsa Mesir. Bahkan pelarian di Midian sesudah membunuh orang Mesir harus dilihat sebagai bagian persiapan Allah bagi Musa (Kel. 2:11-22).

\footnotetext{
${ }^{14}$ W.H. Grispen, Exodus (Grand Rapids, MI: Zondervan Publishing House, 1982)., 41.

15 James Nohrnberg, Like Unto Moses: The Constituting of an Interpretation Indiana Studies in Biblical Literature (Bloomington: Indiana University Press, 1995), 135.
} 
Panggilan Ilahi itu juga lebih kuat dan mengalahkan keraguan dan kelemahan pribadi Musa (Kel. 3-4). Allah menolong Musa untuk mengatasi keraguan dan kelemahannya dengan pelbagai perlengkapan yang dibutuhkannya sebagai seorang pemimpin. Allah memperkenalkan Diri-Nya sebagai AKU ADALAH AKU (Kel. 3:14). Allah memberikan Musa kemampuan untuk melakukan pelbagai mujizat (Kel. 4:2-9). Allah memberikan Harun untuk menjadi pendamping dan juru bicara Musa (Kel. 4:14-16).

Kepemimpinan Alkitabiah bersumberkan pada panggilan Ilahi. Allah memanggil seseorang untuk menjadi seorang pemimpin. Allah yang memanggil itu, Allah yang menyertai dan memperlengkapi pemimpin yang dipilih dan dipanggil-Nya itu.

Hutton mengungkapkan tentang Musa sebagai berikut: "He is the leader of Israel by divine appointment, yet leads at the people's request." Jabatan Musa sebagai pemimpin merupakan panggilan dan pengangkatan Ilahi, tetapi panggilan Ilahi dalam diri Musa terwujud melalui peran kepemimpinan bagi bangsa Israel. Bangsa Israel merasakan dan mengalami manfaat yang besar dari ketaatan Musa terhadap Allah yang memanggilnya sebagai seorang pemimpin.

\section{Kepemimpinan Umum Bergantung Pada Sifat, Kebiasaan, atau Kepribadian Khas Seseorang}

Kartini Kartono juga menyatakan bahwa seorang pemimpin mempunyai sifat, kebiasaan, atau kepribadian khas yang semuanya itu mewarnai perilaku dan gaya kepemimpinan seseorang. ${ }^{17}$ la menyebutkan adanya 8 tipe kemimpinan yang ada, yaitu: ${ }^{18}$

1. Tipe "Deserter" (Pembelot) yang mempunyai karakteristik, seperti bermoral rendah, tidak mempunyai rasa keterlibatan, tanpa pengabdian dan sukar diramalkan.

2. Tipe Burokrat yang mempunyai karakteristik, seperti patuh terhadap peraturan dan norma, terorganisir, tepat dan cermat.

\footnotetext{
${ }^{16}$ Hutton, 40.

17 Kartono, 29-30.

18 lbid,, 30-31.
} 
3. Tipe Misionaris yang mempunyai karakteristik, seperti terbuka, penolong, lembut hati, ramah tamah.

4. Tipe "Developer" (Pembangun) yang mempunyai karakteristik, seperti kreatif, dinamis, inovatif dan mau mendelegasikan.

5. Tipe Otokrat yang mempunyai karakteristik, seperti keras, diktatoris, mau menang sendiri, keras kepala dan sombong.

6. Tipe "Benevolent Autocrat" (Otokrat yang bajik) yang mempunyai karakteristik, seperti tertib, ahli dalam mengorganisir dan mau terlibat langsung.

7. Tipe"Compromiser" yang mempunyai karakteristik, seperti tanpa pendirian, mudah berubah-ubah dan berpandangan pendek.

8. Tipe Eksekutif yang mempunyai karakteristik, seperti bermutu tinggi, motivator, berpandangan jauh dan tekun.

\section{Kepemimpinan Alkitabiah Tak Semata-mata Bergantung Pada Sifat, Kebiasaan, atau Kepribadian Khas Seseorang}

Dalam menafsirkan Kel. 2 Coats mengungkapkan tindakan Musa menolong mereka yang tertindas, baik orang Ibrani sendiri (Kel. 2:11-15a) maupun orang Midian (Kel. 2:15b-22). ${ }^{19} \mathrm{Hal}$ ini menunjukkan bahwa Musa adalah seorang pribadi yang mau membela mereka yang tertindas. ${ }^{20}$ Kel. 32-34 dengan jelas mengungkapkan Musa sebagai pemimpin yang berjuang dan berpihak kepada orang yang dipimpinnya. Musa berdoa syafaat untuk bangsa Israel yang telah memberontak, agar mereka mendapat pengampunan dari Allah. Walaupun ada kisah-kisah yang dapat memberikan petunjuk tentang sifat atau kepribadian Musa, namun tidaklah untuk mengkategorikan tipe kepemimpinan Musa. Brian Bitt menyatakan: "Though he performs many 'signs and wonders', promulgates and administers divine law, and leads the people from Egypt to Kadesh, Sinai, and the Plains of Moab, Moses rarely seems to act on his own initiative." ${ }^{21}$ Kepemimpinan Musa lebih bergantung pada kehendak, rencana dan norma-norma Allah. Kepemimpinan Musa bukan semata-mata bergantung pada sifat, kebiasaan, atau kepribadian khas Musa.

\footnotetext{
${ }^{19}$ Coats, The Moses Tradition, 105.

20 lbid, 107.

21 Brian Bitt, Rewriting Moses. The Narrative Eclipse of the Text. JSOT Supplement Series 402 (London: T \& T Clark International, 2004), 5
} 
Kepemimpinan Alkitabiah bukanlah kepemimpinan yang mandiri (tergantung semata-mata pada diri sang pemimpin), tetapi lebih berupa kepemimpinan teokratis, di mana sang pemimpin tunduk kepada Allah, sang Pemimpin Utama. Oleh karena itu sangatlah sulit untuk mengkategorikan tipe kepemimpinan Musa.

Peran sebagai pemimpin merupakan hanya salah satu dari pelbagai peran Musa. Para ahli Perjanjian Lama menghadirkan Musa dalam pelbagai peran, seperti nabi, imam, raja, hakim, pengantara perjanjian, utusan karismatis, pendiri iman, pemimpin umat dan "inspired shepherd". ${ }^{22}$ Kepemimpinan Musa dapat disebut sebagai kepemimpinan teokratis, di mana Musa sebagai pemimpin bangsa Israel harus tunduk kepada Allah, sang Pemimpin Utama dalam menjalankan tugas kepemimpinannya.

\section{Kepemimpinan Umum Terkait Erat Dengan Kekuasaan, Kewibawaan dan Kemampuan.}

Kartini Kartono menyatkan bahwa ada tiga hal penting yang harus selalu ada dalam kepemimpinan, yaitu: ${ }^{23}$

1. Kekuasaan yang meliputi kekuatan, otoritas dan legalitas yang memberikan wewenang kepada pemimpin untuk mempengaruhi dan menggerakkan bawahan untuk berbuat sesuatu.

2. Kewibawaan yang berkaitan kelebihan atau keunggulan yang menyebabkan seorang pemimpin mampu mengatur orang lain, sehingga orang tersebut patuh pada pemimpin dan bersedia melakukan perbuatan-perbuatan tertentu.

3. Kemampuan yang meliputi kesanggupan dan kecakapan ketrampilan teknis maupun sosial yang dianggap melebihi dari kemampuan anggota biasa.

\section{Kepemimpinan Alkitabiah Juga Berkaitan Dengan Kekuasaan, Kewibawaan dan Kemampuan, Namun Semuanya Itu Tak Terlepas Dari Allah Sebagai Sumbernya}

Tak perlu disangkali bahwa Musa mempunyai kemampuan tertentu yang melebihi orang Israel lainnya, oleh karena

\footnotetext{
22 George W. Coats, Moses. Heroic Man, Man of God. JSOT Sup. Series 57 (Sheffield: JSOT Press, 1988), 34.

${ }^{23}$ Kartono, 31.
} 
kesempatan untuk mendapat pendidikan di istana Firaun, namun kekuatan kepemimpinannya tak terletak utama pada hal-hal itu. Kekuasaan dan kewibawaannya sebagai pemimpin tidak berasal dari pribadi Musa sendiri, tetapi bersumber pada Allah yang memilih dan memanggilnya sebagai pemimpin umat. ${ }^{24}$ Kemampuan supranatural (seperti tulah dan menyeberangi laut Tengah) tentu tak mungkin bersumber pada dirinya, tetapi berasal dari Allah. Dalam kaitan dengan tulah-tulah kepada Mesir James D. Newsome menyatakan: "Moses is portrayed not just as God's agent but as the actual embodiment of the divine presence." 25

Kitab Keluaran menempatkan Musa sebagai "Divine Substitute". ${ }^{26}$ Keluaran 4:16 dan 7:1 menempatkan Musa dalam status Allah ( $\quad)^{27}$ Dalam Keluaran 4:16 Musa ditempatkan sebagai Allah ( $\quad$ ) bagi Harun, sedangkan dalam Kel. 7:1 Musa ditempatkan sebagai Allah ( ) bagi Firaun. Herring juga membahas Musa sebagai "Divine Substitute" berdasarkan Kel. 32$34 .^{28}$ Muka Musa yang bercahaya dan reaksi bangsa Israel seperti reaksi Israel terhadap teophani (penampakan Allah) menempatkan Musa sebagai "Divine Substitute". ${ }^{29}$ Hal yang perlu ditekankan bahwa status khusus ini yang pastinya terkait dengan otoritas dan kewibawaan bukanlah berasal dari diri Musa sendiri, tetapi merupakan karunia dan pemberian Allah kepada Musa untuk menjalankan perannya sebagai pemimpin.

Kewibawaannya sebagai pemimpin juga tergantung pada relasinya dengan Allah. Kitab Keluaran seringkali menyebutnya adanya pertemuan atau komunikasi antara Allah dan Musa. Keluaran 19 menceritakan bahwa Musa harus beberapa kali turun naik ke gunung Sinai dalam kaitan dengan pertemuannya dengan Allah. Begitu juga Keluaran 32-34 juga mengungkapkan pertemuan Musa dengan Allah di gunung Sinai, bahkan pertemuan ini dapat dikatakan berjangka cukup lama.

${ }^{24}$ Coats, Moses. Heroic Man, Man of God, 72.

25 James D. Newsome, Exodus (Louisville, Kentucky: Geneva Press, 1998), 26-27.

${ }^{26}$ Stephen L. Herring, "Moses as Divine Substitute in Exodus," Criswell Theological Review, n.s. 9/2 (Spring 2012), 53-68.

27 lbid, 67.

28 lbid, 54.

${ }^{29}$ lbid, , 54-55, 62-67. 


\section{Kepemimpinan Umum Menyadari Adanya Kecocokan Antara Pemimpin dan Zamannya}

Kartini Kartono mengungkapkan bahwa pemimpin dengan segenap kelebihan dan kekurangannya itu merupakan fungsi dari situasi khusus. ${ }^{30}$ Pemimpin muncul oleh karena sifatnya serasi tepat dan bisa diterima oleh kelompok yang dipimpinnya. ${ }^{31}$ Pemimpin harus cocok dengan situasi dan zamannya. ${ }^{32}$

\section{Kepemimpinan Alkitabiah Juga Menyadari Adanya Kecocokan Antara Pemimpin dan Zamannya}

Peran Musa dalam kehidupan Israel mempunyai sifat umum dan khusus. Bersifat umum, karena karakteristik peran tertentu dapat dilihat pada tokoh-tokoh Perjanjian Lama lainnya. Bersifat khusus, karena karakteristik perannya bersifat khusus untuk Musa dan tak dapat dikenakan kepada tokoh-tokoh lainnya. Musa mempunyai keunikan peran yang tak dapat diulang oleh pemimpin lainnya.

Peran Musa yang jelas adalah memimpin bangsa Israel keluar dari tanah Mesir menuju tanah perjanjian dan mengajar bangsa Israel hukum dan peraturan yang Allah berikan kepada umat-Nya ini. Coats menyatakan bahwa Musa dapat disebut "the Liberator" (peristiwa Keluaran), "the Shepherd" (padang gurun) dan "the Lawagiver" (gunung Sinai). ${ }^{33}$ Sebagai Pembebas ("the Liberator") Musa bukanlah membebas bangsa Israel dari kekuasaan Mesir dengan kemampuannya, tetapi Pembebas Sejati bangsa Israel adalah Allah sendiri. Musa adalah alat atau instrumen Allah dalam membebaskan umat-Nya. Sebagai Gembala ("the Shepherd") Musa memimpin bangsa Israel di padang gurun dengan kemampuannya untuk mencukupi segala kebutuhan mereka dan menjaga kesejahteraan mereka, tetapi Musa adalah alat Allah untuk memimpin dan memelihara umat-Nya di padang gurun. Sebagai Pemberi Hukum ("the Lawagiver") Musa mengajarkan hukum dan peraturan yang ia terima dari Allah.

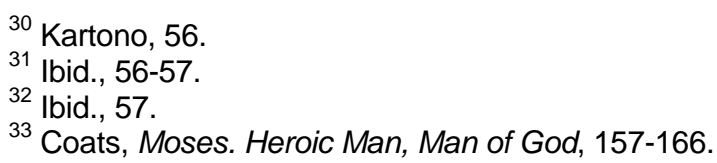


Jelas ada kecocokan antara peran Musa sebagai pemimpin dengan kebutuhan umat yang dipimpinnya dalam eranya. Hal penting yang harus diingat bahwa dalam menjalankan pelbagai peran ini Musa hanya alat atau instrumen Allah. Kepemimpinan Alkitabiah selalu menekankan bahwa seorang pemimpin adalah alat dan bukannya sang pemilik atau penguasa. Seorang pemimpin menjalankan dalam peran yang ditetapkan oleh Allah yang memilih, memanggil dan memperlengkapinya untuk memenuhi kebutuhan umat dalam era tertentu. Hal ini menyebakan adanya kecocokan antara pemimpin yang dipilih dan kebutuhan umat dalam era tertentu.

\section{APLIKASI}

1. Kepemimpinan Musa yang bersumber pada panggilan Ilahi merupakan tipe kepemimpinan yang cocok bagi kepemimpinan Kristiani. Kepemimpinan Kristiani bukanlah bersumber dari warisan dan upaya kudeta sebagaimana kepemimpinan rajaraja Israel umumnya. Kepemimpinan Kristiani tak berpusatkan pada kecakapan khusus seseorang, tetapi lebih pada panggilan llahi. Panggilan Ilahi menjadi pemimpin merupakan hal mutlak untuk seseorang yang mau ("berambisi") menjadi pemimpin Kristiani. Tanpa panggilan llahi itu, jabatan kepemimpinan hanyalah suatu prestasi yang diraih oleh upaya seseorang yang menginginkan kedudukan atau jabatan itu. Jabatan dan kedudukan seorang pemimpin Kristiani adalah suatu anugerah (pemberian) Allah yang diberikan kepada seseorang untuk mengerjakan rencana-Nya bagi umat dalam era tertentu.

2. Allah yang memanggil seseorang untuk menjadi pemimpin, Allah juga yang memperlengkapi pemimpin itu dengan pelbagai kemampuan yang dibutuhkan. Persiapan dan perlengkapan Allah dapat terjadi pada seseorang sebelum atau sesudah ia dipilih oleh Allah menjadi seorang pemimpin. Seseorang yang menyakini panggilan Allah untuk menjadi pemimpin, harus melihat bahwa segala pengalaman hidupnya dapat menjadi persiapan Allah bagi dirinya. la harus juga menyakini bahwa Allah akan memperlengkapi segala yang ia butuhkan dalam menjalani peran sebagai seorang pemimpin. Allah yang memanggil, Allah yang mempersiapkan, memperlengkapi dan bahkan memampukan seorang menjadi pemimpin. 
3. Kepemimpinan Alkitabiah adalah kepemimpinan teokratik di mana sang pemimpin tunduk kepada Allah, sang Pemimpin Utama. Pemimpin Kristiani bukanlah penguasa atau TUAN bagi orang-orang yang dipimpinnya. Seorang pemimpin Kristiani harus senantiasa menyadari bahwa ia sedang menjalankan kepemimpin Allah melalui dirinya. Sebagai pemimpin umat, ia harus senantiasa taat dan tunduk kepada Allah yang merupakan Pemimpin Utama. Kepemimpinan Alkitabiah tak mengajarkan tentang kepemimpinan yang mandiri atau "seenak dan semau" sang pemimpin. Seorang pemimpin Kristiani harus senantiasa sadar bahwa ia ada di bawah kendali Allah yang memilih dan memanggilnya.

4. Pemimpin dilahirkan dan berperan dalam eranya yang khusus. Tak ada seorang pemimpin yang dapat cocok dalam segala era. Seorang pemimpin dipilih, dipersiapkan dan dipanggil oleh Allah untuk menjalankan perannya yang khusus dalam zamannya. Tidak untuk seorang pemimpin yang cocok dalam segala situasi dan zaman. Kesadaran ini menolong seorang pemimpin untuk mempunyai keseimbangan dalam mengenal dan menghargai dirinya. Seorang pemimpin yang dipilih oleh Allah mempunyai peran khusus dan khas dalam eranya untuk menjawab kebutuhan orang-orang yang dipimpinnya. Yang terpenting bagi seorang pemimpin adalah menjalankan sebaik mungkin peran yang ditetapkan Allah bagi dirinya, Hal lain yang perlu diingat adalah bahwa ia dipilih Allah sebagai pemimpin dalam eranya. Suatu saat Allah akan memilih dan membangkitkan pemimpin lain untuk melanjutkan dan menjalan peran kepemimpinan yang lain dalam era yang lain dengan kebutuhan yang berbeda pula. Seorang pemimpin tak hanya siap untuk menjalankan perannya sebagai pemimpin, tetapi ia harus siap juga untuk berkata bahwa peran dan eranya telah selesai serta siap digantikan oleh pemimpin lain yang dipanggil Allah untuk menjalankan peran yang khusus dan khas dalam era yang berbeda pula. 